\title{
Self-inhibition of Germination of Pycnidiospores of Mycosphaerella ligulicola in Relation to the Temperature of their Formation
}

\author{
By J. P. BLAKEMAN \\ Department of Botany, University of Aberdeen, Aberdeen, $A B 92 U D$
}

(Accepted for publication 25 March 1969)

SUMMARY

At high concentrations, self-inhibition of germination of pycnidiospores of Mycosphaerella ligulicola increased with rise in temperature at which the spores were formed.

Spores formed at $15^{\circ}$ ( $15^{\circ}$ spores), which showed little self-inhibition at high concentrations, and $26^{\circ}$ (26 $6^{\circ}$ spores), which showed marked self-inhibition at high concentrations, were used for experiments. Mixing $15^{\circ}$ spores equally with $26^{\circ}$ spores increased inhibition of the latter but the former were unaffected. Leachates from $15^{\circ}$ and $26^{\circ}$ cultures did not affect germination of $26^{\circ}$ and $15^{\circ}$ spores respectively, but germ tubes of $15^{\circ}$ spores showed increased growth. Inhibition of $26^{\circ}$ spores was overcome by washing ten times with deionized water and germ tube growth from washed spores was increased in culture leachates. Diffusates collected from dense suspensions of $26^{\circ}$ spores did not affect germination. Diffusates from $15^{\circ}$ spores prevented germination of $26^{\circ}$ spores but not $15^{\circ}$ spores where growth of germ tubes was increased. The inhibitory substance from $15^{\circ}$ spores was not readily volatile and not affected by high temperature in solution. Volatile inhibitors were not detected from either $15^{\circ}$ or $26^{\circ}$ spores. Pfeffer $1 \%$ glucose solution overcame self-inhibition of $26^{\circ}$ spores but I \% glucose or Pfeffer solution alone were ineffective.

\section{INTRODUCTION}

A rise in incubation temperature of the chrysanthemum ray blight pathogen (Mycosphaerella ligulicola, Baker, Dimock \& Davis) between 12 and $27^{\circ}$ resulted in an increase in pycnidiospore number which was associated with a decrease in size (Blakeman \& Hadley, 1968). Further work (Blakeman \& Fraser, 1969) showed that at high concentrations spores formed at $26^{\circ}$ showed greater self-inhibition of germination when compared with spores formed at $15^{\circ}$. There appear to be no reports of a connexion between incubation temperature of cultures and self-inhibition of the spores for other fungi. The ability of spores, formed over a range of temperatures, to germinate at different concentrations was examined further and the nature of differences in self-inhibition between spores formed at two selected temperatures was investigated.

\section{METHODS}

Spores of Mycosphaerella ligulicola were collected by adding $6 \mathrm{ml}$. of deionized water to the surface of Petri dish potato glucose agar cultures and gently shaking on a rotary shaker for $30 \mathrm{~min}$. The filtrate (referred to as a culture leachate) was removed 
by passage through a membrane filter and the deposit of spores which remained on the membrane was normally washed by passing through two or more batches of $20 \mathrm{ml}$. deionized water. In some cases spores were further washed with up to twenty lots of $20 \mathrm{ml}$. water. The liquid (referred to as a spore leachate) was collected and concentrated after passage through the membrane. The washed spores were removed by cutting the membrane into four strips and shaking in deionized water in a universal bottle. The concentration of the suspension was measured by haemocytometer and diluted as required. Tests were made to determine the effect on germination of culture leachates and spore leachates. Also dense suspensions of previously washed spores were placed in bijou bottles and shaken gently for $\mathbf{2} \mathrm{hr}$ (spores do not germinate under such conditions). After passage through a membrane filter to separate the spores, the filtrate (referred to as a spore diffusate) was tested for its effect on germination. Germination tests were made on Cellophane (British Cellophane Co., PT 300) discs $(\mathrm{I} \cdot 5 \mathrm{~cm}$. diam.), placed on a slide and covered with a coverslip supported on a glass ring which was sealed with petroleum jelly to the slide. All slides were incubated in Petri dish moist chambers for 18,24 or $48 \mathrm{hr}$, after which each portion of Cellophane was transferred to a clean slide, mounted in a drop of acid fuchsin stain and covered with a coverslip which was sealed to the slide with nail varnish. Assessment of germination (from samples of at least 100 spores) and length of the longest germ tube from each spore (from samples of 50 germinated spores) were made on the preserved material. Standard deviations for percentage spore germination were calculated using the arcsin transformation and a ' $t$ ' test was applied to data for germ tube lengths.

The method used to collect volatile materials from spores was as follows. Thirty $\mathrm{ml}$. of dense spore suspension in water was placed in each of four interconnected Dreschler bottles. Filtered air was bubbled through for $6 \mathrm{hr}$ and condensed in a $U$ tube immersed in, or placed $\mathrm{I}$ to $2 \mathrm{~cm}$. above, liquid nitrogen in a Dewar flask. On transference of the tube, after immersion in the liquid nitrogen, to room temperature, condensed oxygen was given off violently causing loss of any volatiles which might have condensed in it. There was no condensation of oxygen when the tube was placed above the nitrogen where the temperature was above the boiling point of oxygen. Alternatively a mixture of solid carbon dioxide in ethanol was used for the condensation. After collection of volatiles the $U$ tube was sealed with rubber stoppers and stored in a deep freeze. The melted contents of the $U$ tube were subsequently tested for their effect on germination of spores of Mycosphaerella ligulicola.

\section{RESULTS}

Rise in incubation temperature, from $\mathrm{I} 2$ to $27^{\circ}$, of cultures of Mycosphaerella ligulicola increased self-inhibition of the spores when tested at concentrations ranging from $0.75 \times 10^{6}$ to $30 \times 10^{6} / \mathrm{ml}$. at $20^{\circ}$ (Fig. 1 ).

Mixing equal numbers of spores formed at $26^{\circ}$ with those formed at $15^{\circ}$ did not prevent germination of the latter but caused increased inhibition in the former. Suspending $26^{\circ}$ spores in leachates from $15^{\circ}$ cultures did not overcome self-inhibition. Conversely there was no decrease in germination on suspending $15^{\circ}$ spores in leachates from $26^{\circ}$ cultures (Fig. 2) and the germ tubes, after $18 \mathrm{hr}$ incubation, were nearly three times as long as those of control spores germinated in water (Table $\mathrm{I}$ ). The number of germ tubes arising from each $15^{\circ}$ spore was nearly twice that from each $26^{\circ}$ spore 
regardless of differences in treatments used. No lateral branches arose from germ tubes of $26^{\circ}$ spores after $18 \mathrm{hr}$ but a few lateral branches had developed from $15^{\circ}$ spores germinated in water and over three times as many from spores suspended in leachates from $26^{\circ}$ cultures.

The effect of prolonged washing on germination of $26^{\circ}$ spores was investigated. Spores washed ten times showed less self-inhibition when compared with unwashed spores. Resuspending washed spores in a culture leachate resulted in 90 to $100 \%$

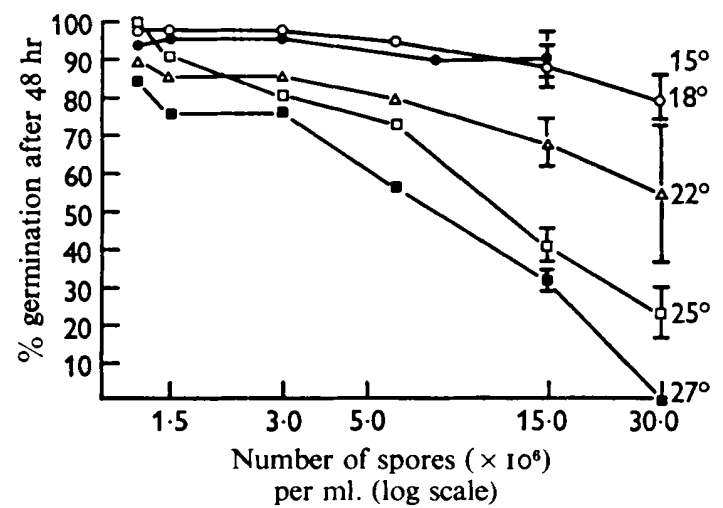

Fig. I

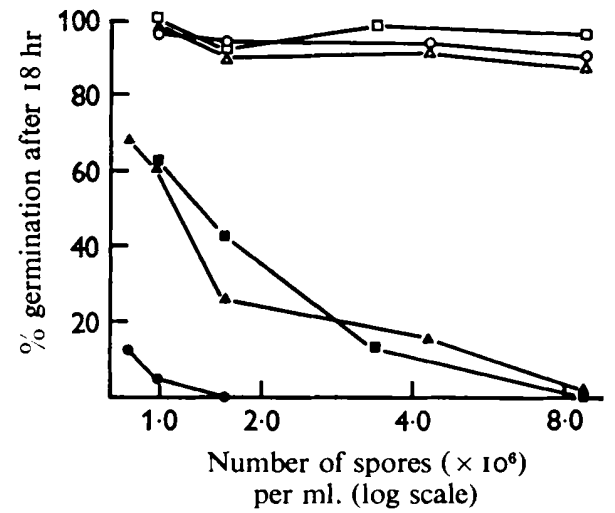

Fig. 2

Fig. 1. Effect of spore concentration on germination of spores of Mycosphaerella ligulicola formed at different temperatures. Standard deviations are given for the higher densities.

Fig. 2. Effect of mixed spore suspensions of Mycosphaerella ligulicola on germination of $15^{\circ}(O)$ and $26^{\circ}(\Theta)$ spores; culture leachates on germination of $15^{\circ}(\triangle)$ and $26^{\circ}(\Delta)$ spores; comparison with germination of $15^{\circ}(\square)$ and $26^{\circ}(\square)$ spores in deionized water.

Table I. Effect of culture leachates on germ tube growth of Mycosphaerella ligulicola

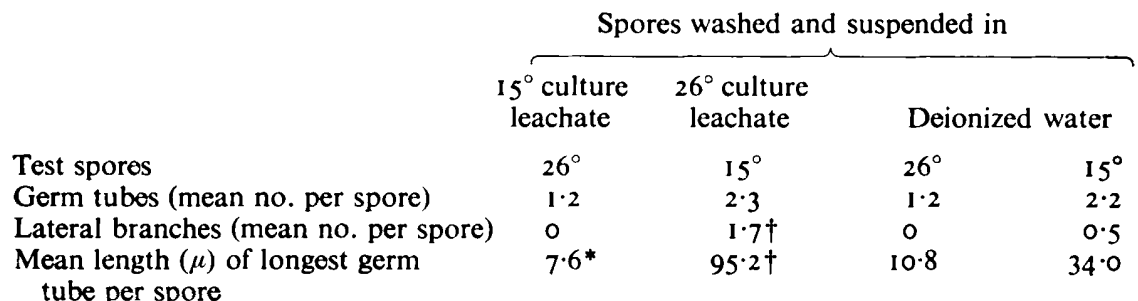

When compared with unwashed controls: ${ }^{*} P=0.01, \dagger P=0.00 \mathrm{I}$.

Measurements made from samples of 50 spores after $18 \mathrm{hr}$ incubation at a concentration of $0.85 \times 10^{6}$ per $\mathrm{ml}$.

germination over the range of spore concentrations tested (Fig. 3). Germ tubes after $48 \mathrm{hr}$ incubation were three times as long after the washing of spores and about fifteen times as long when washed spores were suspended in a culture leachate (Table 2). In the latter the number of germ tubes was nearly twice that of washed or unwashed spores in water. Unwashed spores had no lateral branches after $42 \mathrm{hr}$ but washed spores, suspended in water or culture leachate, had approximately one lateral branch developing from the primary germ tubes from each spore. 


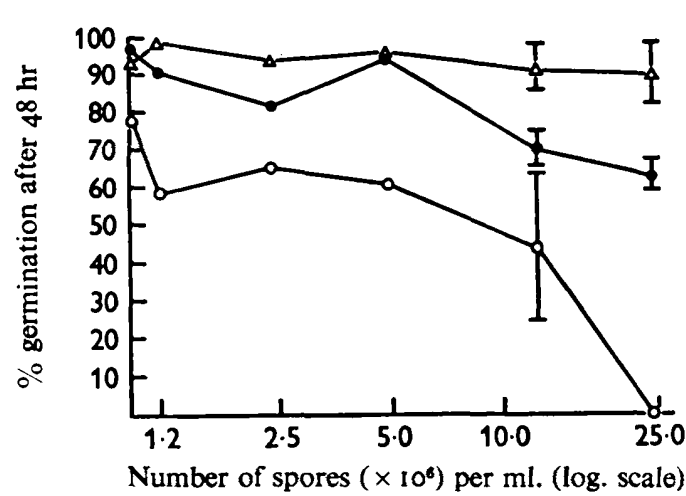

Fig. 3

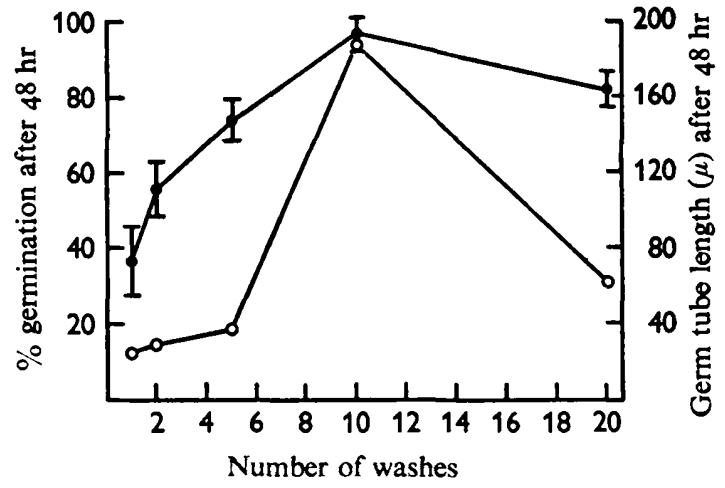

Fig. 4

Fig. 3. Germination of unwashed $26^{\circ}$ spores (O) of Mycosphaerella ligulicola and ten times washed spores suspended in water $(\Theta)$ and in a culture leachate $(\Delta)$ at different concentrations. Standard deviations are given for the higher concentrations.

Fig. 4. Effect of washing on germination $(O)$ and germ tube growth $(O)$ of $26^{\circ}$ spores of Mycosphaerella ligulicola.

Table 2. Effect on germ tube growth of washing and resuspending $26^{\circ}$ spores of Mycosphaerella ligulicola in a culture leachate

Germ tubes (mean no. per spore)

Lateral branches (mean no. per spore)

Mean length $(\mu)$ of longest germ tube per spore

\begin{tabular}{|c|c|c|}
\hline $\begin{array}{l}\text { pores washed } \\
\text { ten times }\end{array}$ & $\begin{array}{l}\text { Spores washod } \\
\text { ten times and } \\
\text { resuspended in } \\
\text { a culture } \\
\text { leachate }\end{array}$ & $\begin{array}{l}\text { Unwashed } \\
\text { spores }\end{array}$ \\
\hline $\begin{array}{c}\mathrm{I} \cdot 5 \\
0.8^{*} \\
27 \cdot 6^{*}\end{array}$ & $\begin{array}{c}2.8 \\
1 \cdot 3^{*} \\
140 \cdot 0^{*}\end{array}$ & $\begin{array}{l}I \cdot 5 \\
0 \\
9 \cdot 2\end{array}$ \\
\hline
\end{tabular}

* $P=0.001$ when compared with unwashed controls.

Measurements made from samples of 50 spores after $48 \mathrm{hr}$ incubation at a concentration of $0.7 \times 10^{6}$ per $\mathrm{ml}$.

Further studies were made by washing $26^{\circ}$ spores once, twice, five, ten and twenty times and testing germination at $30 \times 10^{6}, 3.4 \times 10^{6}$ and $0.65 \times 10^{6}$ spores $/ \mathrm{ml}$. Results (Fig. 4) are given for a concentration of $3.4 \times 10^{6}$. The trends shown at the other concentrations were similar though of a different order. With rise in the number of washes up to ten, germination and growth of germ tubes increased. Suspending spores washed twenty times in a culture leachate increased germination and germ tube growth only at the lowest concentration tested. Suspending washed spores in spore leachates, obtained from concentrating the collected material from twenty washes $(600 \mathrm{ml}$.) to a volume of $3 \mathrm{ml}$. in a rotary evaporator, significantly decreased germination only at the highest concentration tested. At a concentration of $3.4 \times 10^{6}$ spores $/ \mathrm{ml}$. growth of germ tubes was diminished being similar to unwashed control spores, but at $0.65 \times$ $10^{6} / \mathrm{ml}$. germ tubes were shorter than unwashed controls (Table 3 ).

Diffusates from $26^{\circ}$ spores (at concentrations of $36 \times 10^{6}$ and $360 \times 10^{6}$ spores $/ \mathrm{ml}$.) were shown to increase germination and growth of germ tubes of $26^{\circ}$ spores (Table 4 ), the amount depending on the concentration of the diffusate (Table 5). Diffusate from $26^{\circ}$ spores had no effect on germination of $15^{\circ}$ spores (Table 4 ), but, as with $26^{\circ}$ test 


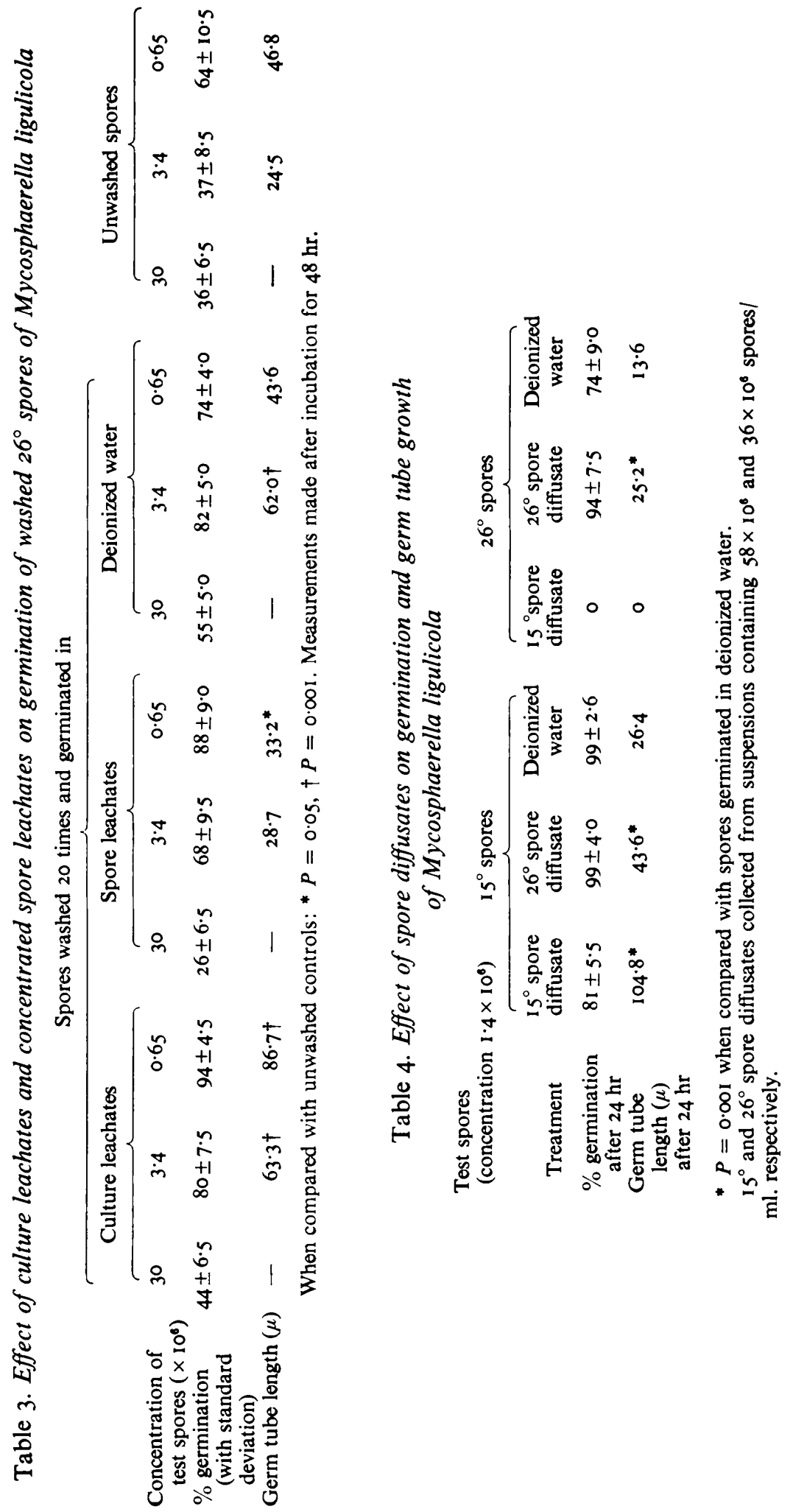


spores, the growth of germ tubes was related to the concentration of the diffusate (Table 5).

Diffusates from $15^{\circ}$ spores (at $46 \times 10^{6}$ and $58 \times 10^{6}$ spores $/ \mathrm{ml}$.) caused a fourfold increase in germ tube growth of $15^{\circ}$ test spores when compared with spores germinated in water. This was accompanied by a small decrease in germination possibly due to rapidly spreading hyphae inhibiting spores which had not germinated. On the other hand, diffusate from $15^{\circ}$ spores caused complete inhibition of germination of $26^{\circ}$ test spores (Table 4). After $48 \mathrm{hr}$ in contact with the diffusate a sample of the spores was removed, washed and transferred to potato glucose agar when only $6 \%$ of the spores

Table 5. Influence of dilution of diffusate from $26^{\circ}$ spores $\left(360 \times 10^{6} / \mathrm{ml}\right.$.) on germination and germ tube growth of 15 and $26^{\circ}$ spores of Mycosphaerella ligulicola

\begin{tabular}{|c|c|c|c|c|c|c|}
\hline \multirow{2}{*}{$\begin{array}{l}\text { Dilution of spore diffusate } \\
\text { Test spores formed at } 15 \text { or } \\
\left.26^{\circ} \text { (Concentration } 1 \cdot 4 \times 10^{6}\right)\end{array}$} & \multicolumn{2}{|c|}{ Undiluted } & \multicolumn{2}{|c|}{$1 / 2$} & \multicolumn{2}{|c|}{$1 / 3$} \\
\hline & 15 & 26 & 15 & 26 & 15 & 26 \\
\hline $\begin{array}{l}\% \text { germination (with } \\
\text { standard deviation) } \\
\text { after } 24 \mathrm{hr}\end{array}$ & $99 \pm 3 \cdot 0$ & $94 \pm 7.5$ & $98 \pm 3 \cdot 5$ & $85 \pm 6.5$ & $98 \pm 4 \cdot 0$ & $8 I \pm 8 \cdot 5$ \\
\hline $\begin{array}{l}\text { Germ-tube length }(\mu) \\
\text { after } 24 \mathrm{hr}\end{array}$ & $92 \cdot 4^{*}$ & $4^{2 \cdot 8^{*}}$ & - & - & - & - \\
\hline Dilution of spore diffusate & \multicolumn{2}{|c|}{$I / 4$} & \multicolumn{2}{|c|}{$1 / 8$} & \multicolumn{2}{|c|}{ Deionized water } \\
\hline $\begin{array}{l}\text { Test spores formed at } 15 \text { or } \\
26^{\circ}\left(\text { Concentration } 1.4 \times 10^{6}\right)\end{array}$ & 15 & 26 & 15 & 26 & 15 & 26 \\
\hline $\begin{array}{l}\% \text { germination (with } \\
\text { standard deviation) } \\
\text { after } 24 \mathrm{hr}\end{array}$ & $100 \pm 0$ & $88 \pm 7 \cdot 0$ & $99 \pm 1 \cdot 0$ & $79 \pm 6 \cdot 0$ & $98 \pm 5 \cdot 0$ & $79 \pm 6 \cdot 0$ \\
\hline $\begin{array}{l}\text { Germ-tube length }(\mu) \\
\text { after } 24 \mathrm{hr}\end{array}$ & $28 \cdot 0^{*}$ & $17 \cdot 6 *$ & - & - & I $2 \cdot 8$ & 6.8 \\
\hline \multicolumn{7}{|c|}{$* P=0.001$ when compared with spores germinated in deionized water. } \\
\hline \multicolumn{7}{|c|}{$\begin{array}{l}\text { Table 6. Influence of dilution of diffusates from } 15^{\circ} \text { spores }\left(58 \times 10^{6} / \mathrm{ml} .\right) \text { on } \\
\text { germination and germ tube growth of } 26^{\circ} \text { spores of Mycosphaerella ligulicola }\end{array}$} \\
\hline $\begin{array}{l}\text { Dilution of } \\
\text { spore diffusate }\end{array}$ & $1 / 2$ & $1 / 3$ & & & $1 / 8$ & $\begin{array}{l}\text { Deionized } \\
\text { water }\end{array}$ \\
\hline $\begin{array}{l}\text { \% germination } \\
\text { (with standard } \\
\text { deviation) after } \\
24 \mathrm{hr}\end{array}$ & $24 \pm 8 \cdot 5$ & $45 \pm 8 \cdot 0$ & & 3.5 & $67 \pm 12 \cdot 5$ & $92 \pm 4 \cdot 0$ \\
\hline $\begin{array}{l}\text { Germ-tube } \\
\text { length }(\mu) \\
\text { after } 24 \mathrm{hr}\end{array}$ & $10 \cdot 0^{*}$ & $11 \cdot 6^{*}$ & & & $11 \cdot 6^{*}$ & $28 \cdot 4$ \\
\hline
\end{tabular}

grew. Dilution of the diffusate caused a steady increase in germination. Growth of germ tubes of those spores able to germinate was decreased in all dilutions tested as compared with water controls (Table 6).

Investigations were made as to whether the inhibitory effect of diffusates from $15^{\circ}$ spores was affected by temperature or was volatile. Samples ( $1 \mathrm{ml}$.) of diffusate were placed in bijou bottles, both capped and uncapped, and maintained at temperatures of $2,20,37$ and $95^{\circ}$ for $18 \mathrm{hr}$. Afterwards the solutions were used at $20^{\circ}$ to 
determine whether they would support germination. There was a complete inhibition of spore germination using diffusates maintained at temperatures of 2,20 and $37^{\circ}$ in both capped and uncapped bottles, and at $95^{\circ}$ in capped bottles only. The diffusate in the uncapped bottle at $95^{\circ}$, which had dried leaving a yellowish deposit, was dissolved in $\mathrm{I} \mathrm{ml}$. deionized water and added to $26^{\circ}$ test spores where it enhanced germination (after $48 \mathrm{hr}$ ) and increased growth of germ tubes by ten times (Table 7 ).

Table 7. Germination of $26^{\circ}$ spores of Mycosphaerella ligulicola at $20^{\circ}$ in diffusate from $15^{\circ}$ spores previously maintained for $18 \mathrm{hr}$ at different temperatures in capped (c) or uncapped $(u c)$ bottles

\begin{tabular}{|c|c|c|c|c|c|c|c|c|c|c|}
\hline & \multicolumn{8}{|c|}{ Temperature $\left({ }^{\circ}\right)$} & \multirow{3}{*}{$\begin{array}{c}\text { Deionized } \\
\text { water } \\
\text { control }\end{array}$} \\
\hline & & \multirow{2}{*}{\multicolumn{2}{|c|}{$\overbrace{}^{2}$}} & \multirow{2}{*}{\multicolumn{2}{|c|}{$\overbrace{}^{20}$}} & \multicolumn{2}{|c|}{$\overbrace{}^{37}$} & \multicolumn{2}{|c|}{$\overbrace{}^{95}$} & \\
\hline & & & & & uc & $c$ & uc & $\mathrm{c}$ & $\widetilde{u c}$ & \\
\hline$\%$ germination & $\begin{array}{l}24 \mathrm{hr} \\
48 \mathrm{hr}\end{array}$ & $\stackrel{\circ}{\circ}$ & $\begin{array}{l}\circ \\
\circ\end{array}$ & $\begin{array}{l}\circ \\
\circ\end{array}$ & $\begin{array}{l}0 \\
0\end{array}$ & $\begin{array}{l}\circ \\
\circ\end{array}$ & $\begin{array}{l}0 \\
0\end{array}$ & $\begin{array}{l}48 \pm 11 \cdot 5 \\
100 \pm 0 \cdot 5\end{array}$ & $\begin{array}{l}0 \\
0\end{array}$ & $\begin{array}{l}53 \pm 9 \cdot 0 \\
69 \pm 6 \cdot 5\end{array}$ \\
\hline \multicolumn{2}{|c|}{ Germ-tube length } & - & - & - & - & - & - & $204^{\circ} 0^{*}$ & - & $21 \cdot 2$ \\
\hline
\end{tabular}

( $\mu$ ) $48 \mathrm{hr}$

* $P=0.001$ when compared with spores germinated in deionizod water.

Concentration of test spores $1.4 \times 10^{6} / \mathrm{ml}$.

Table 8. Germination of spores of Mycosphaerella ligulicola after

$24 \mathrm{hr}$ at different concentrations in water and nutrient solutions

$\begin{array}{ccccc}\begin{array}{c}\text { Spore } \\ \text { concentration/ml. }\end{array} & \text { Water } & \text { I \% glucose } & \text { Pfeffer soln } & \begin{array}{c}\text { Pfeffer soln + glucose } \\ (\mathrm{I} \%)\end{array} \\ 1 \times 10^{8} & 73 \pm 8 \cdot 0^{*} & 53 \pm 15.0 & 79 \pm 4.0 & 84 \pm 6.5 \\ 15 \times 10^{8} & 13 \pm 5.5 & 3 \pm 5.5 & 41 \pm 7 \cdot 0 & 94 \pm 7.5 \\ 30 \times 10^{8} & 0 \pm 1 \cdot 5 & 7 \pm 6.0 & 3 \pm 6.0 & 99 \pm 2.5 \\ & & * \% \text { germination. } & \end{array}$

Table 9. Germ tube length $48 \mathrm{hr}$ after incubation of spores of Mycosphaerella ligulicola at different concentrations in water and nutrient solutions Spore concentration $/ \mathrm{ml}$. Water

$\begin{array}{rc}1 \times 10^{8} & 30.8 \ddagger \\ 15 \times 10^{8} & 12.8 \\ 30 \times 10^{8} & 3.3\end{array}$

$1 \%$ glucose
$74.0 \dagger$
15.6
$11.6 \dagger$

Pfeffer soln
$40 \cdot 8^{*}$
$58 \cdot 8 \dagger$
$20 \cdot 8 \dagger$

When compared with spores germinated in deionized water: $* P=0.05, \dagger P=0.001$.

$\ddagger$ Germ tube length $\mu$.

Addition of condensed volatiles obtained from either $15^{\circ}$ or $26^{\circ}$ spores and collected in a $U$ tube mounted a few $\mathrm{cm}$. above or below the surface of liquid nitrogen or in a mixture of solid carbon dioxide + ethanol caused no change in germination or growth of germ tubes from that of control spores suspended in deionized water.

Tests on the germination of $26^{\circ}$ spores at different concentrations in nutrient solutions demonstrated (Table 8) that addition of $I_{1} \%$ glucose or Pfeffer solution $\left(\mathrm{Ca}\left(\mathrm{NO}_{3}\right)_{2}, 0.8 \mathrm{~g}\right.$.; $\mathrm{MgSO}_{4}$, 0.2 g.; $\mathrm{KNO}_{3}, 0.2 \mathrm{~g}$. $\mathrm{KCl}$, 0.I g.; $\mathrm{K}_{2} \mathrm{HPO}_{4}$, 0.2 g.; traceelement supplement; made to $1 \mathrm{l}$. with deionized water) did not overcome the inhibition of germination shown at high spore concentrations. On the other hand provision 
of Pfeffer solution $+\mathrm{I} \%$ glucose completely overcame the inhibition of germination even at the highest concentration tested $\left(30 \times 10^{6}\right.$ spores $/ \mathrm{ml}$.). The provision of $1 \%$ glucose or Pfeffer solution, separately, in most cases caused some increase in the growth of germ tubes of those spores able to germinate, but much greater increases occurred with Pfeffer solution $+1 \%$ glucose (Table 9).

\section{DISCUSSION}

Self-inhibition of germination of spores of Mycosphaerella ligulicola has been shown to depend on the incubation temperature of the parent culture. Mixing $26^{\circ}$ spores (which show marked self-inhibition related to suspension concentration) equally with $15^{\circ}$ spores (in which self-inhibition is much less evident) showed that the inhibitory condition associated with the former did not affect germination of the latter. But the presence of $15^{\circ}$ spores in the mixture resulted in a greater inhibition of $26^{\circ}$ spores. This suggests that conditions which inhibit germination of $26^{\circ}$ spores are associated with both $15^{\circ}$ and $26^{\circ}$ spores. Either $15^{\circ}$ spores are insensitive to their effects or they possess a mechanism to overcome them.

The possibility that the inhibitory condition originated from the parent culture was examined. Leachates from cultures did not decrease the proportion of germinating $15^{\circ}$ or $26^{\circ}$ spores even at low concentrations but growth of germ tubes of $15^{\circ}$ spores was substantially increased. This indicates that the inhibitory condition may originate from the spores themselves. Attempts were made to remove inhibition by washing the spores. A large increase in the proportion of germinating spores, coupled with the development of longer germ tubes (particularly at high concentrations) occurred with ten times washed $26^{\circ}$ spores. Washed $26^{\circ}$ spores were able to respond to a culture leachate in the same way as unwashed $15^{\circ}$ spores, germ tubes showing a further increase in length. More prolonged washing (20 times) resulted in a slightly decreased germination and shorter germ tubes, due possibly to a decrease in endogenous reserves through leaching. The effect of washing might be to remove a germination inhibitor but application of a concentrated leachate obtained from twenty collected spore washings did not inhibit washed spores at the lower concentrations tested. Only at the highest concentration was there some restriction of germination. The length of germ tubes, however, was decreased at all concentrations. It is possible that washing of spores may have resulted in loss of a substrate required for the formation of an inhibitor.

Diffusates collected from dense suspensions of $26^{\circ}$ spores did not affect germination but caused enhanced growth of germ tubes of both $15^{\circ}$ and $26^{\circ}$ spores. Self-inhibition of $26^{\circ}$ spores would seem therefore not to be due to water-soluble inhibitors diffusing from spores unless these inhibitors were also rapidly labile. Alternatively a sufficient concentration of inhibitors may not have been attained. Only when tested on $15^{\circ}$ spores did diffusates from $15^{\circ}$ spores have the same effect as a $26^{\circ}$ spore diffusate. The observation that diffusates from $15^{\circ}$ spores completely inhibit germination of $26^{\circ}$ spores may explain the increased inhibition of the latter when mixed with $15^{\circ}$ spores. It also shows the greater sensitivity of $26^{\circ}$ spores to inhibitory substances. The active material from $15^{\circ}$ spores is not readily volatile and not affected by prolonged exposure to a high temperature in solution. From these results it is clear that the inhibitor causing self-inhibition of $26^{\circ}$ spores is different in nature from that produced by $15^{\circ}$ spores. 
The presence of volatile inhibitors of spore germination was not detected from suspensions of either $26^{\circ}$ or $15^{\circ}$ spores, though they have been obtained from the mycelium of Fusarium oxysporum (Robinson \& Park, 1966) and from rust uredospores (Allen, 1955.)

The observation that inhibition of germination of $26^{\circ}$ spores at high concentrations can be overcome by provision of a defined nutrient solution might indicate that lack of nutrients was the cause of the inhibition. Nutrients are more likely, however, to overcome an inhibitory condition associated with the spores since germination of spores at high concentrations can take place after prolonged washing of the spores, during which nutrient levels within the spores are likely to be decreased through leaching. The virtual absence of self-inhibition of germination of $15^{\circ}$ spores may be attributed to the higher levels of nutrient reserves contained in the larger spores which may, on germination, overcome the action of inhibitors which have been shown to be associated with these spores. Occasional larger spores present in dense suspensions of $26^{\circ}$ spores were invariably observed to germinate more readily.

\section{REFERENCES}

Allen, P. J. (1955). The role of a self-inhibitor in the germination of rust uredospores. Phytopathology 45, 259.

Blakeman, J. P. \& Fraser, A. K. (1969). The significance of temperature during sporulation on the biology of pycnidiospores of Mycosphaerella ligulicola. Ann. appl. Biol. 63, 295.

Blakeman, J. P. \& Hadley, G. (1968). The pattern of asexual sporulation in Mycosphaerella ligulicola. Trans. Br. mycol. Soc. 5I, 643.

Robinson, P. M. \& PARK, D. (1966). Volatile inhibitors of spore germination produced by fungi. Trans. Br. mycol. Soc. 49, 639. 